\title{
Ischemia Regulates Endoglin Expression in a Pig Skin Flap Model
}

\author{
Toni Nimeh, Roya Haghighat-Mortazavi, M.Sc., Kayvan Khiabani, M.D., \\ Noura Malek, B.Sc., Kevin Watters, M.D., and Anie Philip, Ph.D.*
}

\begin{abstract}
Endoglin is a transmembrane protein that binds transforming growth factor $\beta$ (TGF- $\beta$ ) with high affinity. It is thought to modulate TGF- $\beta$ signaling and responses through interactions on cell surfaces with TGF- $\beta$ receptors. It is highly expressed on endothelial cells of tissues undergoing angiogenesis. Since ischemia-induced changes such as angiogenesis are in part regulated by TGF- $\beta$, it is important to elucidate the precise mechanism by which they occur if we are to influence the effects of ischemia on tissue. Since endoglin is one of the receptors involved in regulating TGF- $\beta$ signaling, we tested whether endoglin expression will increase in response to ischemic injury. A pig skin flap model was developed and used in our laboratory to study the effect of ischemia on the expression of endoglin and its ligand TGF- $\beta 1$ using immunohistochemistry. We observed an increased expression of endoglin and TGF- $\beta 1$ in the epidermal layer, blood vessels, and fibroblasts in ischemic skin flaps as compared to non-ischemic control skin flaps. Given the role of TGF- $\beta$ and endoglin in angiogenesis, this may represent a mechanism by which ischemia stimulates angiogenesis. Much work remains to be done to delineate the exact mechanisms by which TGF- $\beta$ acts and the exact role of endoglin in TGF- $\beta$ signaling. Understanding how to regulate the actions of TGF- $\beta$ by manipulating the expression of endoglin may provide a therapeutic avenue given the importance of TGF- $\beta$ in tumour angiogenesis.
\end{abstract}

\section{INTRODUCTION}

Angiogenesis is the formation of new blood vessels. It occurs in diverse physiological and pathological situations such as wound healing, tumour growth, and diabetic retinopathy (1). Angiogenesis is complex process potentiated by certain factors and inhibited by others (2). Delineation of these factors is key in modifying pathologic angiogenesis in tumor growth, and in understanding the mechanisms of induction of angiogenesis in ischemic tissue.

The deleterious effects of ischemic injury in the body are mediated by oxygen free radicals such as superoxide anions, and by local cytokines such as interleukin 1 (IL-1)

\footnotetext{
*To whom correspondence should be addressed: Dr. Anie Philip, Montreal General Hospital, room C9-177. 1650 Cedar Avenue, Montreal, Quebec, H3G 1A4 Canada Phone: (514) 937-6011 ext 4533; Fax: (514) 934-8289; e-mail: mcap@musica.mcgill.ca.
}

and tumor necrosis factor $\alpha$ (TNF- $\alpha$ ). However, not all upregulated cytokines are deleterious; trasforming growth factor $\beta$ (TGF- $\beta$ ) has been shown to attenuate ischemic tissue damage in addition to stimulating angiogenesis (3-5). It is an important protein involved in vascular remodeling. It enhances wound healing and has been shown to be protective against ischemiareperfusion injury in the heart and the brain (6-8).

In man, TGF- $\beta$ exerts its effects by acting on a family of receptors including receptors types I (RI) and II (RII), as well as on betaglycan (RIII) and endoglin (CD 105) $(9,10)$. TGF- $\beta$ receptors type I and II are involved in signal transduction. TGF- $\beta$ binds RII, which results in the recruitment, phosphosphorylation, and activation of RI. RI activates other downstream mediators such as Smads, which in turn regulate the target gene expression (11,12). Betaglycan (RIII) and Endoglin (CD 105) are not involved in signal transduction, but in modulation of the TGF- $\beta$ signal by regulating TGF- $\beta$ 's 
access to RI and RII. Betaglycan is a proteoglycan that presents TGF- $\beta$ to RII, increasing binding of TGF- $\beta$ to RII $(12,14)$. Endoglin is a transmembrane protein that binds TGF- $\beta 1$ and 3 with high affinity $(15,16)$. It is a homodimeric glycoprotein that has been shown to form a heteromeric complex with RI and RII $(14,17)$. It has a strong homology with betaglycan in the transmembrane intracellular domain $(18,19)$. It is thought to modulate TGF- $\beta$ signaling and responses through interactions on cell surfaces with TGF- $\beta$ receptors. It is highly expressed on endothelial cells of tissues undergoing angiogenesis, such as tumours, healing wounds, psoriasis, and embryonic and stroke tissue (20-25). Endoglin's preferential expression in the vasculature of malignant tumors is of particular interest given its potential diagnostic and therapeutic applications. Endoglin has been localized to human chromosome 9 (26) and is the target gene for hemorrhagic telangiectasia type-1 (HHT-1), or Osler-Weber-Rendue disease $(27,28)$.

Since ischemia-induced changes in tissue are in part regulated by TGF- $\beta$, it is important to elucidate the precise mechanism by which they occur if we are to influence the effects of ischemia on angiogenesis. We have previously demonstrated that TGF- $\beta$ and its receptors type I, II, and III are upregulated in ischemic injury in vivo. This upregulation of TGF- $\beta$ function in ischemia might play a factor in the ischemia-induced angiogenesis seen in ischemic tissue. Since endoglin is one of the receptors involved in regulating TGF- $\beta$ signaling, we tested whether endoglin expression will increase in response to ischemic injury. In the present study we demonstrate an increased expression of endoglin, and its ligand TGF- $\beta 1$ in the epidermal layer, blood vessels, and fibroblasts in ischemic skin flaps as compared to non-ischemic control skin flaps.

\section{MATERIALS AND METHODS}

\section{Animal Management and Surgical Preperations}

The protocol for use of pigs in this experiment was approved by the McGill Universtiy Animal Care Committee. Six female, White Lancrace pigs (10-14 weeks old) were housed in a temperature-controlled $\left(20-22^{\circ} \mathrm{C}\right)$ animal holding room. All the pigs were offered the same commercial pig diet and tap water $a d$ libitum. Food was withheld the evening of the surgery. Animals were sedated with intramuscular injections of ketamine $(20 \mathrm{mg} / \mathrm{kg})$ and xylazine $(2 \mathrm{mg} / \mathrm{kg})$ and then received $1 \mathrm{mg}$ Atropine. Intravenous dose of sodium pentobarbital $(6 \mathrm{mg} / \mathrm{kg})$ was administered. General anesthesia was maintained during all procedures with spontaneous inhalation of oxygen $(81 / \mathrm{min})$ and halothane (0.5-1.0\%). A bilateral $10 \mathrm{~cm} \times 18 \mathrm{~cm}$ flap design connected through a vascular pedicle that contains the superficial circumflex artery and its accompanying vena comitantes as well as the lateral femoral cutaneous nerve was used as a skin flap (29).

Arterial ischemia in island flaps was created by clamp application on the artery and used to mimic the clinical scenario of an ischemic free flap. The flap on one side was assigned to 1 hour of arterial occlusion with the contralateral side acting as a nonischemic control. Complete occlusion of the vasculature was achieved by application of an Acland V2 microvascular clamp to the branch of the circumflex iliac artery supplying buttock flaps. Ischemia was verified by application of $10 \%$ sodium fluorescein $(15 \mathrm{mg} / \mathrm{kg})$ dye. Absence of fluorescein in the skin 15 minutes after dye injection indicated complete occlusion of the vascular pedicle. Samples were taken at 1 hour from flaps.

\section{Tissue samples}

Skin biopsies collected from pig flaps were fixed in $4 \%$ paraformaldehyde for 8 hours followed by $15 \%$ sucrose solution for 30 hours at $4{ }^{\circ} \mathrm{C}$. They were embedded in Tissue Tek compound and frozen in liquid nitrogen. Frozen tissues were cut using a cryostat. Each slide had at least two copies of the two different sets of tissues namely control non-ischemic flap and ischemic flap. This helped to control for variations in intensity of staining as might occur during the procedure, e.g. during the peroxidase reaction (see below).

\section{Polyclonal antibodies}

The antibody against Endoglin EG (591-609) was a gift from Dr. Miyazono (Ludwig Institute for Cancer Research, Uppsala, Sweden); the method of preparation has been described previously (18). The antibody against TGF- $\beta 1$ was a gift from Dr. O'Connor-McCourt (Biotechnology Research Institute, Montreal, Quebec, Canada).

\section{Immunohistochemistry Staining Procedures}

Staining was performed using an indirect immunoperoxidase technique. Negative control (absent primary antibody) stainings were included. In brief, 8 mm thick Cryosections on gelatin coated glass slides were washed and permeabilized three times at room temperature each for 15 min with phosphate-buffered saline (PBS), $0.1 \%$ triton $\mathrm{X}-100, \mathrm{pH} 7.5$. Then they were treated for $10 \mathrm{~min}$ at room temperature with $3 \%$ $\mathrm{H}_{2} \mathrm{O}_{2}$ in $99 \%$ methanol, to block endogenous peroxidase activity. They were incubated in a humidifier chamber for $10 \mathrm{~min}$ at room temperature with $10 \%$ normal goat serum, $0.3 \%$ triton, and $0.5 \%$ bovine serum albumin (BSA) in PBS. Anti-endoglin was diluted to a final dilution of 1:400 in blocking 

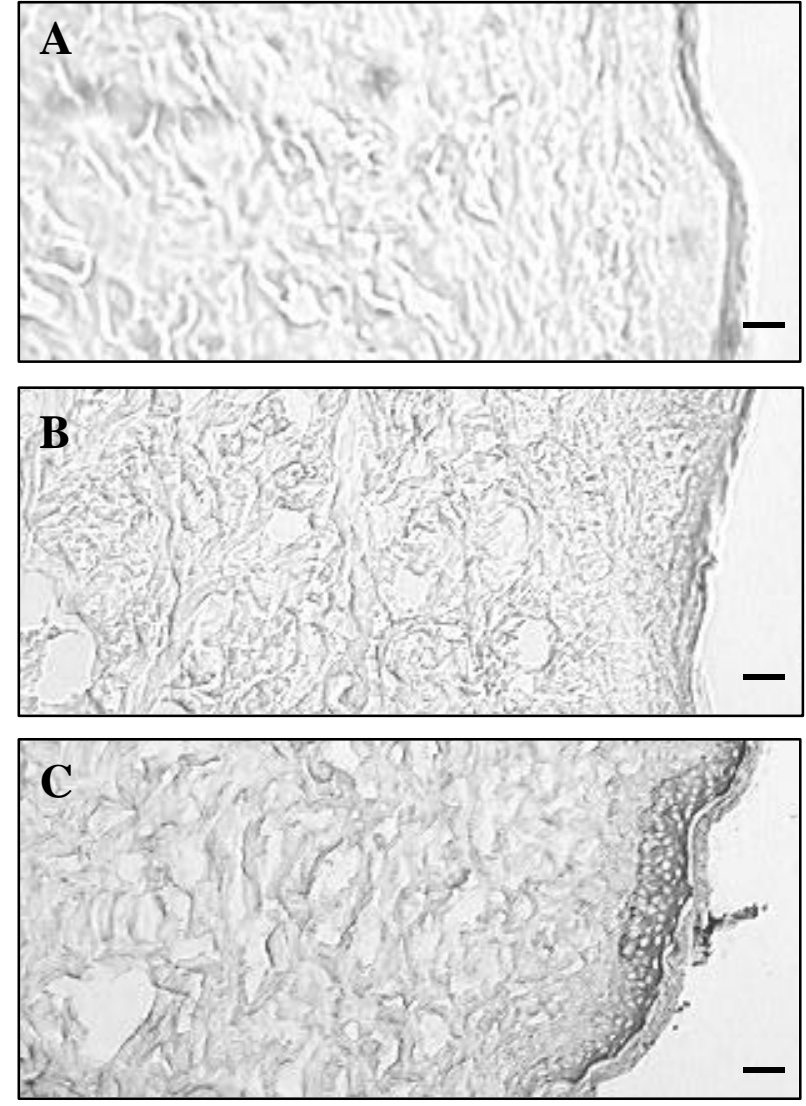

Figure 1. Endoglin expression in skin. A: Control for immunostaining (no primary antibody); B: Non-ischemic tissue; C: Ischemic tissue. Scale bar $=40 \mu \mathrm{m}$

solution. Anti-TGF- $\beta 1$ was diluted to a final dilution of 1:160. These primary antibodies were applied to the sections for a duration of 1 hour at room temperature. The slides were then incubated in biotinylated goat antirabbit secondary antibody for $10 \mathrm{~min}$. and in streptavidin-peroxidase (HRP) for $10 \mathrm{~min}$. The slides were stained with 3-amion-9-ethyl-carbazole $200 \mathrm{mg} / \mathrm{l}$ in sodium acetate buffer and $0.01 \% \mathrm{H}_{2} \mathrm{O}_{2}$ (AEC solution). The slides were washed between each incubation with PBS. The slides were finally washed with demineralized water, counterstained with Mayer's haematoxylin (Sigma, St. Louis, MO) and mounted in glycerine gelatine.

\section{Histological Examination}

Slides were analyzed by light microscopy. Using a 4point scale, the staining level was assessed at the epidermal region, in the blood vessels, and in the skin fibroblasts in a blinded fashion, without knowledge of whether the flaps were from control or ischemic groups. The structures with the most staining were assigned 4 points, where the ones with the least staining were assigned 1 point. The $p$ values were determined by a non-parametric Wilcoxon Signed Rank Test $(30,31)$.
Table 1. Immunostaining for TGF- $\beta 1$ and endoglin in control versus ischemic tissues.

\begin{tabular}{|c|c|c|}
\hline \multirow[b]{2}{*}{ Tissue } & \multicolumn{2}{|c|}{ Expression Levels } \\
\hline & TGF- $\beta 1$ & Endoglin \\
\hline \multicolumn{3}{|l|}{ Epidermis } \\
\hline Control & 1.00 & 1.00 \\
\hline Ischemia & 2.50 & 2.97 \\
\hline \multicolumn{3}{|l|}{ Blood Vessels } \\
\hline Control & 1.00 & 1.37 \\
\hline Ischemia & 2.25 & 3.00 \\
\hline \multicolumn{3}{|l|}{ Fibroblasts } \\
\hline Control & 1.00 & 1.70 \\
\hline Ischemia & 2.25 & 3.00 \\
\hline
\end{tabular}

\section{RESULTS}

Immunohistochemical localization of TGF- $\beta 1$ and endoglin was performed in tissue sections prepared from buttock skin flaps of pigs. The expression profiles of these proteins were analyzed in non-ischemic control flaps and ischemic flaps. The skin structures immunostained for the ligand TGF- $\beta 1$ and for the receptor endoglin were in general similar between ischemic and non-ischemic flaps (Figure 1). Comparative analysis of immunostaining for TGF- $\beta 1$ and endoglin revealed that the expression of both these proteins was increased in the ischemic flaps compared to the non-ischemic flaps (Table 1). The skin structures that showed the most dramatic increases were the blood vessels (endothelial cells), fibroblasts, and the basal layer of the epidermis (basal keratinocytes) (Figure 1).

\section{Epidermis}

There was a significant increase in immunostaining for TGF- $\beta 1$ in the epidermis of ischemic flaps (2.50) as compared with control (1.00) $(p<0.031)$. We observed a cytoplasmic granular staining in the keratinocytes of the epidermis of endoglin-stained tissue. This is the first report of keratinocyte-expression of the endoglin receptor. There was a significant increase in immunostaining for endoglin in the epidermis of ischemic flaps (2.97) compared to control flaps (1.00) $(p<0.0026)$.

\section{Blood Vessels}

There was a significant increase in immunostaining for TGF- $\beta 1$ in the blood vessels of ischemic flaps (2.25) compared to control flaps $(1.0)(p<0.031)$. There was also a significant increase in immunostaining for endoglin in the blood vessels of ischemic flaps (3.00) compared to control flaps (1.37) $(p<0.0026)$.

\section{Fibroblasts}

There was a significant increase in immunostaining for TGF- $\beta 1$ in the fibroblasts of ischemic flaps (2.25) compared to control flaps $(1.00)(p<0.031)$. There was 
also a significant increase in immunostaining for endoglin in the fibroblasts of ischemic flaps (3.00) compared with control flaps (1.70) $(\mathrm{p}<0.007)$.

\section{DISCUSSION}

We used a pig skin flap model to study the effect of ischemia on the expression of endoglin and its ligand TGF- $\beta 1$. In our comparison, the effect of wounding itself on the flap was minimized by comparing ischemic skin flaps to non-ischemic control flaps rather than to unoperated skin. Thus, any changes observed were solely due to the effect of ischemia on the flap. The major finding of the study was the observation of an increased expression of endoglin, and its ligand TGF- $\beta 1$ in the epidermal layer, blood vessels, and fibroblasts in ischemic skin flaps compared to nonischemic control skin flaps.

The cellular TGF- $\beta$ receptor system consists of several membrane receptors including receptor type I (RI), II (RII), III (RIII or betaglycan) and endoglin. Receptors type I and II are responsible for TGF- $\beta$ 's signal transduction which is in turn modulated by betaglycan and endoglin, both of which have no direct function in signal transduction. Our data indicate that the expression of TGF- $\beta$ increases under ischemic conditions. Given the role of TGF- $\beta$ in angiogenesis, this may represent a mechanism by which ischemia stimulates angiogenesis. Although TGF- $\beta 1$ inhibits endothelial cell proliferation in vitro, it strongly induces angiogenesis in in vivo assays such as the chick chorioallantoic membrane assay (5). Ex vivo studies in human tissue showed that TGF- $\beta 1$ is present in tissues undergoing neovascularization (24). An explanation for the conflicting findings of in vitro versus in vivo studies is that the role of TGF- $\beta$ is to recruit inflammatory cells into the immediate vicinity of the applied stimulus, and these cells will subsequently secrete positive mediators of angiogenesis, such as vascular endothelial growth factor (VEGF) (5). TGF- $\beta$ may therefore be an indirect, but necessary player in angiogenesis in vivo.

Letamendia et al. found that endoglin inhibits the TGF- $\beta 1$-dependent responses of cellular proliferation $(32,33)$. Endoglin binds TGF- $\beta 1$ much more weakly than betaglycan, and only in the presence of RII, as opposed to betaglycan which can bind TGF- $\beta 1$ independently of RII. Endoglin's potentiation of TGF$\beta 1$ 's binding to its receptors remains hard to reconcile with its inhibitory effect on TGF- $\beta$ signaling. Letamendia et al. proposed a model where the RIIinduced ligand binding to endoglin is actually a deflection of the ligand from the signaling core and thus may represent an inhibition of TGF- $\beta$ signaling.

TGF- $\beta$ clearly inhibits endothelial cell growth, migration, and capillary formation in vitro (34-36). Endoglin, on the other hand, weakens TGF- $\beta$ 's inhibitory effect on endothelial cells, resulting in an increased cell migration. By antagonizing TGF- $\beta$ 's effects on endothelial cells, endoglin may contribute to the proliferation, migration, and capillary formation of endothelial cells (37). This explains the defective vascular development in the endoglin-knockout mouse (38), as well as the symptoms seen in HHT-1, where endoglin is the affected gene.

This explanation is also consistent with our results where both TGF- $\beta$ and endoglin are upregulated in ischemia. We believe that both of these factors are needed in angiogenesis. We propose a model for the role of TGF- $\beta$ in angiogenesis (Figure 2) where TGF- $\beta$ first rises under the direct influence of ischemia, and acts by recruiting inflammatory cells which secrete the necessary growth factors acting on endothelial cells, resulting in angiogenesis. Subsequently, TGF- $\beta$ signaling is inhibited by endoglin which permits endothelial cells to escape TGF- $\beta$ 's negative influence and proliferate to form new blood vessels. Subsequently, TGF- $\beta$ acts on the formed blood vessels to induce endothelial quiescence and vessel maturation. 
This final step is not well characterized, but is necessary if the endothelial cells are not to proliferate without inhibition, therein becoming malignant.

We are gaining more insight into the complexities of angiogenesis: We now realize that angiogenesis is not an event, but a multi-step heterogeneous process. The idea that certain factors 'stimulate angiogenesis' is being replaced by the concept that certain factors or their receptors may stimulate or inhibit very specific steps in angiogenesis. With this idea, it is possible to reconcile much of the confusion and the contradictions related to the role of TGF- $\beta$ and endoglin in angiogenesis.

Much work remains to be done to delineate the exact mechanisms by which TGF- $\beta$ acts and the precise role of endoglin in this complex cascade. Understanding how to regulate the actions of TGF- $\beta$ by manipulating endoglin's expression may provide a therapeutic avenue given the importance of TGF- $\beta$ in tumour angiogenesis.

\section{REFERENCES}

1. Folkman J. Angiogenesis in cancer, vascular, rheumatoid and other diseases. Nature Medicine 1995; 1: 27-31.

2. Kumar P. CD 105 and angiogenesis. Journal of Pathology 1996; 178: 363-366.

3. Roberts $\mathrm{AB}$, Sporn MB. Physiological actions and clinical applications of transforming growth factor- $\beta$ (TGF- $\beta$ ). Growth Factors 1993; 8: 1-9.

4. Roberts AB, Sporn MB, Assoian RK, et al. Transforming growth factor $\beta$ : rapid induction of fibrosis and angiogenesis in vivo. Proceedings of the National Academy of Science USA 1986; 83: 4167-4171.

5. Yang EY, Moses HL. Transforming growth factor $\beta 1$-induced changes in cell migration, proliferation and angiogenesis in the chick choriallantoic membrane. Journal of Cell Biology 1990; 111: 731-741.

6. Lefer AM, Ma XL, Weyrich AS, Scalia R. Mechanism of the cardioprotective effect of transforming growth factor beta 1 in feline myocardial ischemia and reperfusion. Proceedings of the National Academy of Sciences USA 1993; 90: 1018-1022.

7. McNeill H, Williams C, Guan J, et al. Neuronal rescue with transforming growth factor-beta 1 after hypoxic-ischaemic brain injury. Neuroreport 1994; 5: 901-904.

8. Mehta JL, Yang BC, Strates BS, Mehta P. Role of TGF- $\beta 1$ in platelet-mediated cardioprotection during ischemia-reperfusion in isolated rat hearts. Growth Factors. 1999; 16: 179-190.

9. Miyazono K, Ten-Dijke P, Ichijo H, Heldin CH. Receptors for transforming growth factor- $\beta$. Advances in Immunology 1994; 55: $181-220$.

10. Massague J, Attisano L, Wrana JL. The TGF- $\beta$ family and its composite receptors. Trends in Cell Biology 1994; 4: 172-178.

11. Wrana JL, Attisano L, Wieser R, et al. Mechanism of activation of the TGF- $\beta$ receptor. Nature 1994; 370: 341-347.

12. ten Kijke T, Yamashita H, Ichijo H, et al. Characterization of type I receptors for transforming growth factor-beta and activin. Science 1994; 264: 101-104.

13. Moustakas A, Lin HY, Henis YI, et al. The transforming growth factor beta receptors type I, II, and III form hetero-oligomeric complexes in the presence of ligand. Journal of Biological Chemistry 1993: 268: 22215-22218.

14. Lopez-Casillas F, Wrana JL, Massague J. Betaglycan presents ligand to the TGF- $\beta$ signaling receptor. Cell 1993; 73: 1435-1444.
15. Gougos A, Letarte M. Primary structure of endoglin, an RGDcontaining glycoprotein of human endothelial cells. Journal of Biological Chemistry 1990; 265: 8361-8364.

16. Cheifetz S, Bellón T, Calés C, et al. Endoglin is a component of the transforming growth factor- $\beta$ receptor system in human endothelial cells. Journal of Biological Chemistry 1992; 267: 19027-19030.

17. Yamashita H, Ichijo H, Grimsby S, et al. Endoglin forms a heteromeric complex with the signaling receptors for transforming growth factor- $\beta$. Journal of Biological Chemistry 1994; 269: 1995-2001.

18. Lopez-Casillas F, Chiefetz S, Doody J, et al. Structure and expression of the membrane proteolgycan betaglycan, a component of the TGF- $\beta$ receptor. Cell 1991; 67: 785-95

19. Wang XF, Lin HY, Ng-Eaton E, et al. Expression, cloning and characterization of the TGF- $\beta$ type III Receptor. Cell 1991; 67: 797-805.

20. Letarte M, Breaves A, Vera S. CD 105 (endoglin). In: Scholossman SF et al., eds. Leucocyte Typing V. Oxford: Oxford University Press, 1995: 1756-1759.

21. Westphal JR, Willems HW, Schalkwijk, CJM, et al. Characteristics and possible function of endoglin. A TGF- $\beta$ binding protein. Behring Institute Mitteilungen 1993; 92: 15-22.

22. Gougos A, St-jacques S, Greaves A, et al. Identification of distinct epitopes of endoglin, an RGD-containing glycoprotein of endothelial cells, leukaemic cells and syncytiotrophoblasts. International Immunology 1992: 4: 83-92.

23. Krupinski J, Kumar P, Kumar S, Kaluza J. Increased expression of TGF- $\beta 1$ in brain tissue after ischemic stroke in humans. Stroke 1996; 27: 852-857.

24. Wang JM, Kumar S, Pye D, et al. Breast carcinoma: comparative study of tumor vasculature using two endothelial cell markers. Journal of the National Cancer Institute 1994; 86: 386-388.

25. Wang JM, Kumar S, van Agthoven AJ, et al. Irradiation induces up-regulation of E9 protein (CD105) in human vascular endothelial cells. International Journal of Cancer 1995; 62: 791796.

26. Lopez-Casillas F, Payne HM, Andres JL, Massague J. Betaglycan can act as a dual modulator of TGF- $\beta$ access to signaling receptors: mapping of ligand binding and GAG attachment sites. Journal of Cell Biology 1994; 124: 557-568.

27. McAllister KA, Grogg KM, Johnson DW, et al. Endoglin, a TGF- $\beta$ binding protein of endothelial cells, is the gene for hereditary haemorrhagic telangiectasia type 1 . Nature Genetics 1994; 8: 345-351.

28. McAllister KA, Baldwin MA, Thukkani AK, et al. Six additional mutations in the endoglin gene in HHT1 suggest a dominant-negative effect of receptor function. Human Molecular Genetics 1995; 4: 1983-1985.

29. Picard-Ami LA Jr, Thomson JG, Kerrigan CL. Critical ischemia times and survival patterns of experimental pig flaps. Plastic and Reconstructive Surgery 1990; 86: 739-743.

30. Conover WJ. Practical Nonparametric Statistics, 2nd ed. New York: Wiley, 1980.

31. Lehmann EL. Nonparametrics: Statistical Methods Based on Ranks. San Francisco: Holden and Day, 1975.

32. Letamendia A, Lastres P, Botella LM, et al. Role of endoglin in cellular responses to transforming growth factor- $\beta$. Journal of Biological Chemistry 1998; 273: 33011-33019.

33. Lastres $\mathrm{P}$, Letamendía A, Zhang $\mathrm{H}$, et al. Endoglin modulates cellular responses to TGF- $\beta 1$. Journal of Cell Biology 1996; 133: $1109-1121$.

34. Sutton AB, Canfield AE, Schor SL, et al. The response of endothelial cells to TGF- $\beta 1$ is dependent upon cell shape, 
proliferative state and the nature of the substratum. Journal of Cell Science 1991; 99: 777-787.

35. Klein-Soyer C, Archipoff G, Beretz A, Cazenave JP. Opposing effects of heparin with TGF- $\beta$ or aFGF during repair of a mechanical wound of human endothelium. Biology of the Cell 1992; $75: 155-162$

36. Takashima S, Klagsbrun M. Inhibition of endothelial cell growth by macrophage-like U-937 cell-derived oncostatin M, leukemia inhibitory factor, and transforming growth factor $\beta 1$. Journal of Biological Chemistry 1996; 271: 24901-24906.

37. Li C, Hampson IN, Hampson L, et al. CD105 antagonizes the inhibitory signaling of transforming growth factor betal on human vascular endothelial cells. FASEB Journal 2000; 14: 55-64.

38. Li DY, Sorensen LK, Brook BS, et al. Defective angiogenesis in mice lacking endoglin. Science 1999; 284: 1534-1537.

Toni Nimeh is currently a third year medical student at McGill University. Roya Haghighat-Mortazavi obtained a M.Sc. degree from the McGill's Department of Pathology and is currently working towards a Ph.D. degree. Dr. Kayvan Taghipur Khiabani is trained as an MD and specializes in plastic surgery. Currently he is doing a surgical fellowship in Las Vegas. Noura Malek obtained her B.Sc. from Concordia University and is a now working as a registered technologist in Montreal General Hospital. Dr Kevin Watters, MD is now an Associate Professor of Pathology in the Pathology Department of McGill university. Dr. Anie Philip obtained both MSc and PhD training at McGill University, where she is currently an Assistant Professor of Surgery. 